\title{
ヒト末梢リンパ球に及ぽすプラトニンの作用
}

\author{
耿排力・近藤 直実・元吉 史昭 \\ 金子英雄 - 寺澤総介・平野通子・折居忠夫 \\ Jpn. J. Clin. Immun., 10(1):66 70, 1987.
}

\section{Effects of platonin on human peripher:l blood lymphocytes}

\author{
Hairiki Ko, Naomi Kondo, Fumiaki Motoyoshi, \\ Hideo Kaneko, Sosuke Terasawa, Yukiko Hirano and Tadao Orii
}

Department of Pediatrics, Gifu University School of Medicine

\begin{abstract}
【Summary】
The effect of Platonin on human peripheral blood lymphocytes (PBL) was studied in vitro. Platonin showed proliferative effect on PBL. When PBL was stimulated with $T$ cell mitogen Phytohemagglutinin (PHA) and B cell mitogen Staphylococcus aureus Cowan I (Cowan I), it showed enhancing effect on the former and suppressive effect on the latter. In Pokeweed mitogen (PWM) induced immunoglobulin (Ig) productive system, both of the T.B cells, T cells only, or B cells only were pretreated with Platonin and then co-cultured. The Ig secreting cells were demonstrately decreased than that of the absent Platonin pretreated in any groups. However, the ${ }^{3} \mathrm{H}$-thymidine incorporation failed to give a significant variation in any groups. In the experiment of $\mathrm{T}$ cell subsets detected with monoclonal antibodies and by Fluorescent Activaed Cell Sortor (FACS), the $\mathrm{OKT}^{+} \mathrm{T}$ cells showed a high proportion in the Platonin treated groups. In summary, B cells were directly suppressed by Platonin and concerning $T$ cells, the $T$ cell subsets showed a high proportion of suppressor/killer $T$ cells. So it is suggested that Platonin suppressed Ig prodution through suppressing B cells and enhancing suppressor/killer $\mathrm{T}$ cells.
\end{abstract}

Key words : Platonin, peripheral blood lymphocytes

\section{【概 要】}

プラトニンのヒト免疫系に及ぼす作用を末梢リンパ球（PBL）を用いて検啥した. プラトニンは PBL の幼若化反 応に対しては促進的に作用したが，T細胞マイトゲン Phytohemagglutinin (PHA)， B 細胞マイトゲン Staphylo. coccus aureus Cowan I (Cowan I) で刺激した場合, 前者に賦活作用を示し, 後者に逆に軽度抑制作用を示した. Pokeweed mitogen (PWM) 誘導 Ig 産生系を用いた検討では， T 細胞分画， B 細胞分画のいずれか一方または両方 
をプラトニンで処理すると，末処理に比し，Ig 分泌細胞は著しく減少したが, ${ }^{3} \mathrm{H}$-thymidine の取込みは変化しなかっ た. 単クローン抗体によるT細胞サブセットの分析では, プラトニンにより OKT 8 陽性T細胞の比率が増加する傾 向が認められた. 以上のことから，B細胞はプラトニンにより直接的に抑制を受けたが，T細胞については，Fluorescent activated cell sortor (FACS) を用いた T 細胞サブセットに関する成績から，ヘルパー，インデューサーT 細 胞を抑制するのではなく，むしろサプレッサー，キラーT細胞を賦活することにより Ig 産生を抑制するものと考え られた。

\section{I. 緒言}

プラトニン (Platonin (NK 19) (4, 4'-dimethyl-3, 3'. di-n-heplyl-8-[2-(4-methyl-3-n-heptylthiazole)]-2, 2'. di-carbocyanine diiodine) は trithiazole pentamethine cyanine 系感光色素の 1 つであり, マウスの T細胞を賦 活，B 細胞を抑制するとされている1 3). またヒトでは慢 性関節リウマチや若年性関節リウマチなどに有効である と報告されている4,5). 薬理作用として抗菌作用, 創傷治 溗促進作用, 網内系造血藏器や内分泌腺賦活作用などを 有することが知られている6).しかし，七ト免疫系に及ぼ す作用やその作用機序については不明である. そこで, 著者らはヒト末梢リンパ球を用いてプラトニンの免疫系 に及ぼす作用につき検討した。

\section{II. 対象および方法}

\section{1. 細胞分離}

健康人 (10〜32 歳) のヘパリン加末梢血から FicollIsopaque を用いた比重遠心法により単核球 (PBL) を分 離した. さらに一部の PBL を neuraminidase 処理七 ッジ赤血球によりロゼットを形成させた後, 再び FicollIsopaque を用いた比重遠心法およびナイロンウールカ ラム法により $\mathrm{T}$ 細胞分画 ( $\mathrm{T}$ 細胞) と $\mathrm{B}$ 細胞分画 (B 細 胞) とに分離した. なお， $\mathrm{T}$ 細胞の純度は $94 \%$ 以上， $\mathrm{B}$ 細胞の純度は $78 \%$ 以上であり，それぞれの viability は 95\% 以上であった.

\section{2. ブラトニン}

日本感光色素研究所梀から購入したものを用いた. 使 用時, プラトニンをリン酸緩衝液(PBS, pH 7.4) で溶か し，それぞれ $50,5,0.5,0.05 \mu \mathrm{g} / \mathrm{m} l$ の漂度で使用した。

\section{3. マイトゲン}

Phytohemagglutinin-M (PHA-M, GIBCO. Lab, USA); Staphylococcus aureus Cowan I (Cowan I, Calbiochem-Behring Corp.); Pokeweed mitogen (PWM, GIBCO. Lab, USA）はいずれも蒸留水で溶かし使用し た.

\section{4. 培養条件}

$10 \mathrm{mM}$ の N-2-hydroxyethylpiperazine-N-2-ethanesulfonic acid (HEPES), $2 \mathrm{mM} の$ L-glutamine, $100 \mathrm{IU} /$ $\mathrm{m} l$ の penicillin, $100 \mu \mathrm{g} / \mathrm{m} l$ の streptomycin および 15 \%非働化胎児ウシ血清 (FCS) を含んだ RPMI 1640 溶液

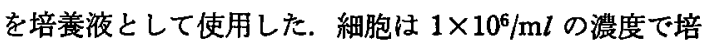
羕液に浮遊させ，培養はマイクロプレート(A/S Nunc), あるいは培羡チューブで $37^{\circ} \mathrm{C} 5 \% \mathrm{CO}_{2}$ を含んだ培美器 内で下記のごとく一定期間行った.

\section{5. リンパ球幼若化反応の測定}

細胞 (PBL) 浮遊液をマイクロプレートに $2 \times 10^{5} / 0.2$ $\mathrm{m} l /$ ウルの割で入れ，PHA あるいは Cowan I 0.1 $\mu \mathrm{g} / \mathrm{m} l$ の存在あるいは非存在下にそれぞれの濃度のプラ トニンを加えた. 3 日間培養後, 各ウェルに ${ }^{3} \mathrm{H}$-thymidine ( ${ }^{3} \mathrm{H}-\mathrm{TdR}, 5 \mathrm{Ci} / \mathrm{m} \mathrm{mol}$, Amersham UK) $0.5 \mu \mathrm{Ci}$ 加え, 4 時間後にセルハーベスターで細胞を採集し, 液 体シンチレーションカウンターで細胞に取り込まれた ${ }^{3} \mathrm{H}$ の放射活性をカウントした，なお，測定は少なくとも triplicate で行った.

\section{6. 免疫グロブリン (Ig) 分泌細胞の検出}

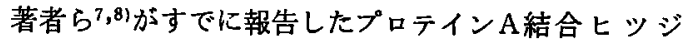
赤血球を用いたプラーク法により行った.すなわち、プ ロテイン A (Pharmacia) $0.5 \mathrm{mg} / \mathrm{ml}$ を $\mathrm{CrCl}_{3}, 6 \mathrm{H}_{2} \mathrm{O}$ を用いてヒッジ赤血球に結合させ，25\%の minimum essential medium (MEM) 溶液 (Microbiological Associates, Mayland) に浮遊させ標的細胞とした.

PBL を培養液に $1 \times 10^{6} / \mathrm{ml}$ の濃度に浮遊させ, Cowan I $0.1 \mu \mathrm{g} / \mathrm{m} l$ あるいは PWM $10 \mu \mathrm{g} / \mathrm{m} l$ 存在下に各震度 のプラトニンを添加して 7 日間培養した後、MEM で 1 回洗浄し, $1 \mathrm{ml}$ の MEM に浮遊させた. ついでプロテイ ン A 結合ヒツジ赤血球浮遊液 $0.05 \mathrm{~m} l, \mathrm{PBL}$ 浮遊液 0.1 $\mathrm{m} l$, 抗ヒト Ig 血清 $0.025 \mathrm{~m} l$ (医学生物研究所) およひ モルモット補体 $0.025 \mathrm{ml}$ (極東製薬) を混合し，その $0.1 \mathrm{ml}$ を Cunningham チャンバー内に入れ，パラフィ ンで封じ, $37^{\circ} \mathrm{C}$ で 6〜12 時間インキュベートし，肉眼で プラーク，形成細胞 (PFC) 数を算定した.なお、抗ヒト Ig 


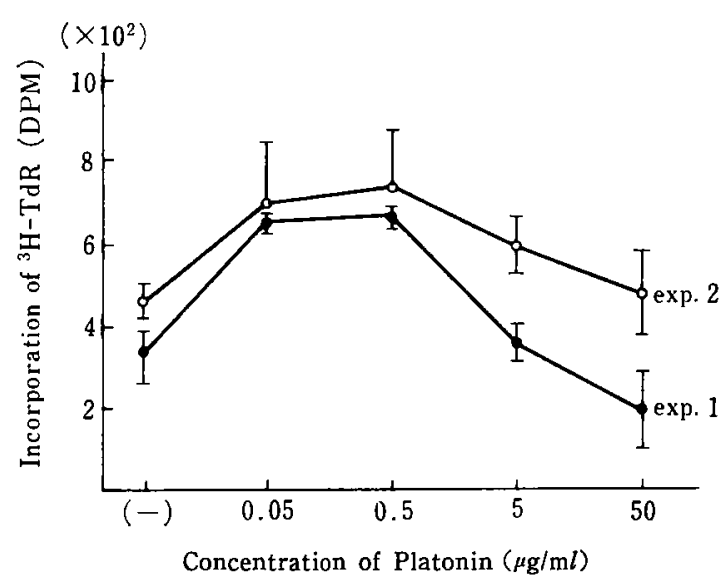

Effect of Platonin on human peripheral blood lymphocytes without mitogen stimulation

図 1

血清として，抗ヒト $\gamma$ 鎖血清，抗ヒト $\mu$ 鎖血清，抗ヒト $\alpha$ 鎖血清を使用した時に出現する PFC を，それぞれ IgG, IgM, IgA 分泌細胞とした. PFC 数はウェルあたり で示したが，一部の成績は対照群の PFC 数に対する実 験群の PFC 数を百分率で示した.

$$
\left(\% \mathrm{PFC}=\frac{\text { 実験群の PFC 数 }}{\text { 対照群の PFC 数 }} \times 100\right)
$$

7. $\mathrm{T}, \mathrm{B}$ 細胞の組み合わせによる Ig 分泌細胞の検出 $\mathrm{T}$ 細胞, B 細胞を培養液で $1 \times 10^{6} / \mathrm{m} l$ に調整し，これ らの細胞のいずれか一方または両方をプラトニン（5 $\mu \mathrm{g} / \mathrm{m} l)$ で $37^{\circ} \mathrm{C} 5 \% \mathrm{CO}_{2}$ 培美器内で 24 時間インキュべ ートした. その後それぞれの細胞を PBS (pH 7.4)で 3 回洗浄し，再び $1 \times 10^{6} / \mathrm{m} l$ に調整した. 細胞の viability は約 72〜86\%であった.これらの T細胞, B 細胞をそれ ぞれ $0.1 \mathrm{~m} l$ ずつマイクロプレートの各ウェルに入れ， PWM $(10 \mu \mathrm{g} / \mathrm{m} l)$ 存在下で培羕を開始し, 培養 3 日後， 前述と同様に ${ }^{3} \mathrm{H}-\mathrm{T} \mathrm{dR}$ の摂取率を測定し，7 日後に PFC の測定を行った.

\section{8. 単クローン抗体による $\mathbf{T}$ 細胞サブセットの分析} PBL を培養液で $1 \times 10^{6} / \mathrm{m} l$ に調整し, 各浱度のプラト ニンおよび $10 \mu \mathrm{g} / \mathrm{m} l$ の PHA を加え，培養チューブに て $37^{\circ} \mathrm{C} 5 \% \mathrm{CO}_{2}$ 培坆器で 3 日間培養後, PBS (pH 7.4) で 2 回洗浄し, 再度 PBS で $1 \times 10^{6} / \mathrm{m} l$ に調整した。これ らの PBL 浮遊液を $100 \mu l$, FITC 結合単クローン抗体 (OKT 3, OKT 4, OKT 8, OKT 11, オーソ・ダイアグ) スティック・システムズ)を $10 \mu l$ ずつ各チューブに入 れ，十分かくはんした後， $4^{\circ} \mathrm{C} 30$ 分インキュベートし，

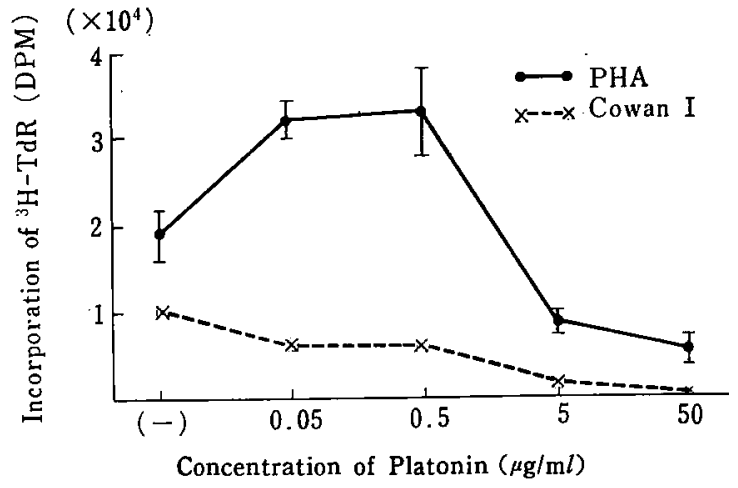

Effect of Platonin on PBL stimulated with PHA or Cowan I

図 2

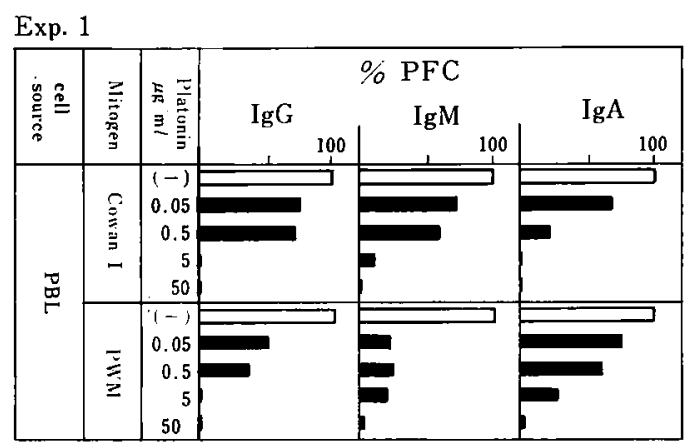

Effect of Platonin on plaque forming cells stimulated with Cowan I or PWM

図 3

PBS (pH 7.4) で 2 回洗浄 L, Fluorescent activated cell sortor (FACS, Ortho. USA) で分析した.

\section{III. 成 績}

1. プラトニンによる PBL の幼若化反応

図1に示されるように, 健康人 PBL はプラトニンに より幼若化反応を示した，すなわち，0.05, $0.5 \mu \mathrm{g} / \mathrm{ml}$ の 源加で ${ }^{3} \mathrm{H}-\mathrm{TdR}$ の掑取率は極大值を示した。

\section{2. マイトゲンによる PBL の幼若化反応に及ぼすプ ラトニンの影響}

健康人 PBL の PHA による幼若化反応はプラトニン により増強したが，Cowan I による幼若化反応はプラト ニンにより軽度抑制された（図 2 ）.

3. PBL の Cowan I あるいは PWM 誘導 Ig 産生に 及ほすプラトニンの影響

図3,4に示されるように, PBL の Cowan I あるいは 


$$
\text { 耿・ヒト末梢リンパ球に及ぼすプラトニンの作用 }
$$

PWM による Ig 産生はプラトニンの湍度に依存して抑 制された.

\section{PWM 誘導 Ig 産生系を用いた $\mathrm{T}, \mathrm{B}$ 細胞の組み 合わせによる挨討}

$\mathrm{T}$ 細胞, $\mathrm{B}$ 細胞のいずれか一方または両方をプラトニ ンで処理した後, 組み合わせて培養すると, 各群の ${ }^{3} \mathrm{H}-$ $\mathrm{TdR}$ の摂取率は変化しなかったが, Ig 分泌細胞の検出 では，T細胞，B 細胞のいずれか一方または両方をプラ トニンで処理すると, 未処理に比し, Ig 分泌細胞は著し く減少した (図 5 ).

\section{T 細胞サブセットの FACS による分析} プラトニンはヒトT細胞に対しては賦活的に作用する

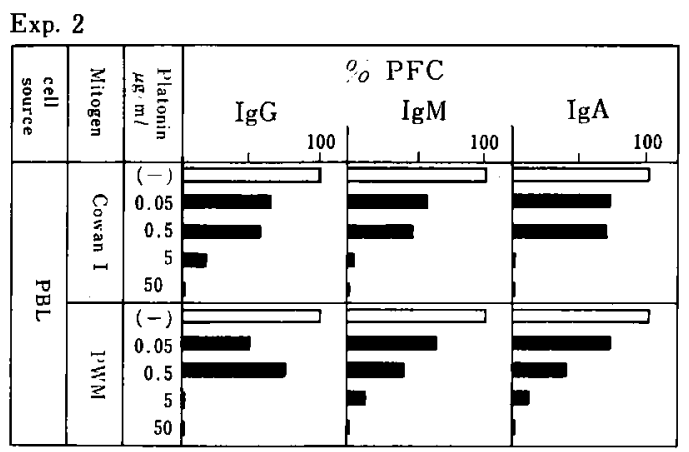

Effect of Platonin on plaque forming cells stimulated with Cowan I or PWM

図 4
むののT細胞サブセットに影響を与えるかどうかについ て，プラトニン処理による $\mathrm{T}$ 細胞サブセットの変動を FACS により分析したところ，図 6 に示されるように, OKT 8 細胞の比率が増加する傾向が認められた.

\section{IV. 考按}

プラトニンは慢性関節リウマチや若年性関節リウマチ などの治療に有効であると報告されている4,5). またマウ スでは T 細胞を賦活，B 細胞を抑制するとされている1 3). 本研究はヒト末梢リンパ球に及ぼすプラトニンの作 用やその免疫薬理学的機序を明らかにする目的からヒト PBL, T 細胞, B 細胞を用いて検討した.

プラトニンは PBL の纤若化に対して 0.05, $0.5 \mu \mathrm{g} / \mathrm{m} l$ の漕度で明らかな反応を示したが， $\mathrm{T}$ 細胞マイトゲン (PHA), B 細胞マイトゲン (Cowan I) で刺激した場合， 前者に賦活作用を示し，後者に逆に軽度抑制作用を示し た.PWM 誘導 Ig 産生系を用いた成績では,プラトニン は Ig 産生を抑制した.このうち B 細胞はプラトニンに より直接的に抑制を受けたが， T細胞については，FACS を用いたT細胞サブセットに及ぼす成績から、へルパー， インデューサーT細胞を抑制するのではなく，むしろサ プレッサーキラー T 細胞を賦活することにより Ig 産 生を抑制するむのと考えられた. Strelkauslas ら ${ }^{9,10)}$ 慢性関節リウマチの病態に T 細胞特に Ts 細胞 (サプレ ッサー $\mathbf{T}$ 細胞) の機能障害を指摘している. したがっ て、プラトニンの抗リウマチ剂として働く機序の 1 つに サプレッサーT細胞を賦活して，その作用を発揮して いく可能性が考えられた.

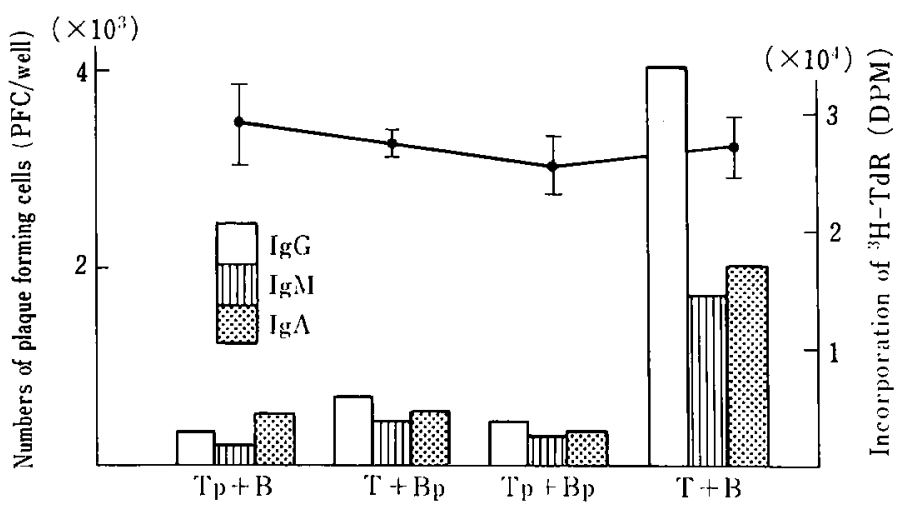

Effect of Platonin on proliferation (incorporation of ${ }^{3} \mathrm{H}-\mathrm{TdR}$ ) and differentiation (detection of plaque forming cells) of $T$ cells and $\mathrm{B}$ cells in co-culture system with pokeweed mitogen.

$\begin{array}{ll}\mathrm{T}: \mathrm{T} \text { cells } & \mathrm{Tp}: \mathrm{T} \text { cells treated with platonin for } 1 \text { day. } \\ \mathrm{B}: \mathrm{B} \text { cells } & \mathrm{Bp}: \mathrm{B} \text { cells treated with platonin for } 1 \text { day. }\end{array}$ 


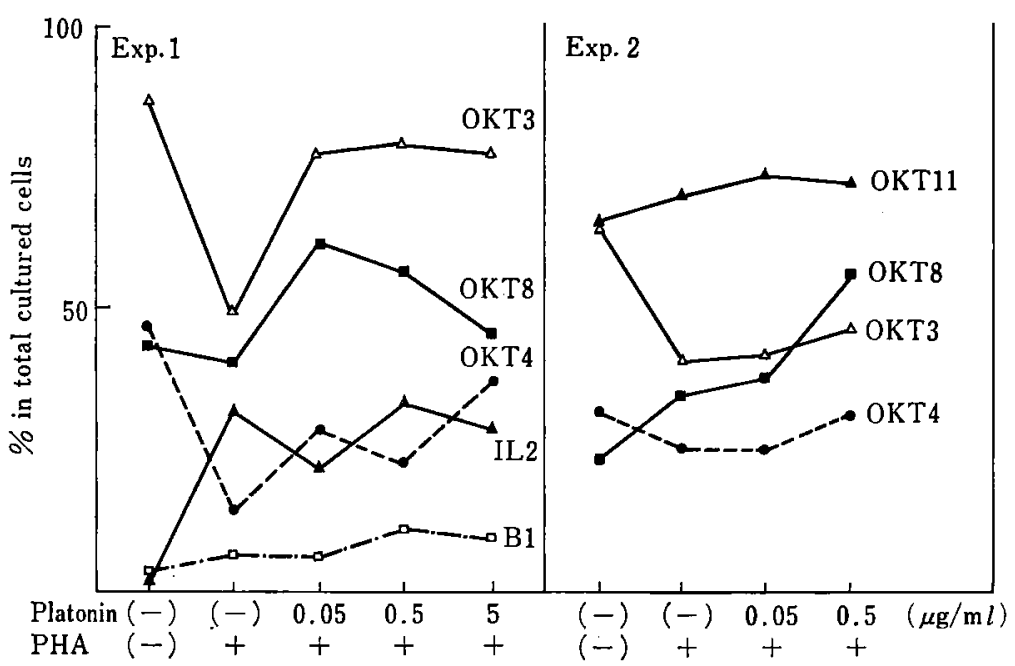

Effect of Platonin on $T$ cell subsets detected with FACS analyzer

図 6

免疫疾患の場合 $\mathrm{T}$ 細胞の機能がいろいろな原因で障害 され， $\mathrm{T}$ 細胞の働きが弱くなったため， B 細胞の活性が 六進していくとも考えられている ${ }^{11,12)}$ ，その点で免疫治

文

1) 山本 格·内藤万紀 : 免疫調節剂としての Platonin (NK 19) の評価 (I) マウス脾細胞 PFC 応 答及び ${ }^{3} \mathrm{H}-\mathrm{TdR}$ 取込みに関する研究. 感光色 素, $88: 31 \sim 39,1981$.

2) 山本 格. 大熊重則・辻 淳一・松浦栄次 : 免疫 調節剤としての Platonin（NK 19）の評価（II） In vivo 抗体応答ならびにアジュバント関節炎に 対する作用. 感光色素, $89: 26 \sim 34,1984$.

3) 山本 格 - 中山妙子 : Platonin と Lumin のリン パ球幼若化反応ならびに in vitro 抗体応答に対す る作用の比較. 感光色素, $88: 57 \sim 58,1981$.

4）波多野元久 - 山田多啓男 - 吉田 哲 - 竹内直文 野呂貞子 ·渡辺一彦: 神経痛, 関節リウマチ等に 対する感光色素プラトニン (Platonin) の使用経 験. 感光色素, $84: 4 \sim 8,1975$.

5）小野博正 - 篠田練司 - 耿 排力 · 清水信雄 - 近藤 直実・折居忠夫 : 若年性関節リウマチに対するプ ラトニンの効果. 吱阜医紀要, 印刷中.

6) プラトニン文献集, 株式会社 日本感光色素研究 所, 岡山, 1976, pp. 15 32.

7) 近藤直実 - 折居忠夫 - 植竹久雄 : Pokeweed mitogen 誘導免疫グロブリン産生采におけるヒト同 種 T-B 細胞間の適格性の存在とその解析. アレ
療剤としてのプラトニンは障害された T細胞の機能を回 復し，六進された B 細胞の機能を抑え，以わゆる免疫調 整剂として働くものと考えられた.

献

ルギー, $30: 281 \sim 288,1981$.

8) Kondo, N., Uetake, H. : Effect of human $T$ cell culture supernatants on polyclonal immuno. globulin secretion of Iymphoblastoid cell lines transformed by Epstein-Barr virus. Ann. Rep. Inst. Virus. Res. Kyoto Univ., 22 : 29 34, 1979.

9) Strelkauslas, A.J., Schauf, V., Wilson, B.S., Chess, L., Schlossman, S.F. : lsolation and characterization of naturally occuring subclasses of human peripheral blood $\mathrm{T}$ cells with regulatory functions. J Immunol., $120: 1278 \sim 1282$, 1978.

10) Strelkauslas, A.J., Chelley, R.T., Madowell, J., Borel, Y., Schlossman, S.F. : Direct evidence for loss of human suppressor cells, during active autoimmune disease. Proc. Natl. Acad. Sci. USA., 75 : 5150 5154, 1978.

11）坂根 㓮:IV. 兔疫学の医学への応用 3 全身性 エリテマトーデスにおける T 細胞機能. 代謝 16 (臨時増刊号)：1943～1953，1979.

12）吉本 敬 : 特集自己免疫発症機序一最 近の考え 方一 $\mathrm{T}$ 細胞の異常・臨床免疫 $12: 265 \sim 269,1980$. 